\title{
Functional efficiency of stand with soil-conservation erosion control function on the forest unit Banská Bystrica - Ulanka
}

\author{
J. Jankov'1), K. Gubka ${ }^{21}$ \\ ${ }^{1)}$ Municipal Forests Banská Bystrica Ltd., Dolný Harmanec 51/3, 97603 Harmanec, Slovak Republic, E-mail: \\ jozefjankov@gmail.com, \\ ${ }^{2)}$ Technical University in Zvolen, Faculty of Forestry, Department of Silviculture, T. G. Masaryk 24, 96053 \\ Zvolen, Slovak Republic,E-mail:gubka@tuzvo.sk
}

\begin{abstract}
Jankov J., Gubka K. 2014: Functional efficiency of stand with soil-conservation erosion control function on the forest unit Banská Bystrica - Ul'anka. - Beskydy, 7 (1): 47-58

The paper analyses functional efficiency of stand with soil-conservation erosion control function. The object of research was the subcompartment $1160 \mathrm{~d}$ on the forest unit Banská Bystrica - Ul'anka. In the stand was established the network of six permanent sample plots, where the basic characters of structure were recorded and functional efficiency of trees was estimated. The subject of the research was also an analysis of abundance of natural regeneration. As follows from the research, the stand fulfils the requirement placed on ecosystems with the preferential soil-conservation erosion control function. From the total number of trees, 51\% was assessed as functionally highly efficient. On all permanent sample plots there is natural regeneration in progress. On the basis of functional efficiency practical measures were proposed to improve the existing state.
\end{abstract}

Key words: stand structure, functional efficiency, soil-conservation erosion control function

\section{Introduction}

Soil erosion is a natural process existing milliard years on the Earth. People started observing its existence mainly in connexion with the lost of soil fertility and subsequent shortage of food. The population explosion of mankind in the last centuries has negatively influenced the soil erosion processes up to extend, that today in significant way directly or indirectly influences every human being and almost every fields of their activity. Soil erosion is increasingly connected with the shortage of drinking water, which is at present word-wide more pressing problem than food shortage.

Soil erosion is the most significant form of physical destruction of soils also on the territory of Slovakia. From the knowledge of soil erosion problems up to now we know that the most suitable and the most effective measure of soil protection against erosion is functionally efficient forest, with suitable humus forms. The forest should be vigorous, with species, age, and spatial diversity. In this respect, herbal cover is also of not negligible significance. In the stable, healthy, undisturbed forest ecosystems the soil lost due to erosion are minimal (Jakubis 2006).

The soil-conservation erosion control function of forest is management and ecological determination of forest, aiming at utilization of forest stand for soil conservation against its destruction by surface runoff in the form of surface und rill water erosion (Midriak 1979). The categorisation of the SR forests is regulated by law No 326/2005 Statute Book on forest and Regulation of Ministry of Industry SR No 453/2006 on forest management and forest conservation. According to the Green report (2013), in the Slovak Republic 331240 ha is classified in the category of protection forest, out of which $76.97 \%$ have erosion control function. The soil-conservation erosion control function in protection forests is dominant, but it is necessary to realise that it is significantly applied also in the functional 
types of wood-producing forests, as well as in the forests with environmental function (multipurpose forests) (Gubka 2006).

Principles and influences of management in the forests with soil-conservation erosion control function were dealt e.g. by Intribus et al. (1979), Midriak et al. (1981), Jurča et al. (1986), Röhrig et al. (1992), Réh (1993, 1999), Dvořák, Novák (1994), Valtýni (2001), Kantor, Šach (2002), Kucbel (2005), Podrázský, Kupka (2011) and others. From the conclusions of these works follows that from the viewpoint of soil-conservation erosion control function of the forest, the compact stands with the tree species suitable for the site, with full stocking, with perfect vertical canopy closure, and optimal interception can be considered the most suitable. In such structuralized stands, fewer precipitations with high kinetic energy penetrate to soil. The condition of forest litter as well as the physical and chemical properties of soil (microbial activity of organisms, structure of soil horizons, and depth of rhirosphere ...) are also significant factors. It is emphasize, that the development of protection forests communities cannot be left only to natural processes, not controlled by man, because disturbing breakdown of these communities could most probably cause the lost of their functional efficiency. In general, we can say that it primarily concerns an ensuring the basic characters of functional type of forest structure. The basic postulate of permanent fulfilment of water-retention ability of forests is their constant existence on the area. From the above given follows that it is necessary to use such silvicultural measures which meet the declared requirements (Saniga et al. 2011). From the conceptions of forest management, selection forest, or vertically differentiated forest, is considered the best and the most stable stand type for protection forest and for the functionally integrated forestry. For broadleaved stands is the most suitable type the small-scale form of shelterwood system, where the main principle lays in sustainability of forest ecosystem with permanent fulfilling of all functions on each unit of the area (Mayer, Ott 1991; Korpel', Saniga 1995; Gubka 1997, Saniga 2009; Saniga, Bruchánik 2009).

The aim of the submitted paper is an analysis of the structure, the functional efficiency and regeneration processes of the stand with soil-conservation erosion control function on the forest unit Banská Bystrica - Ul'anka. In the case of need, on the basis of analysis to elaborate the proposal of measures for improvement the present state.

\section{Material and Methods}

The chosen object is situated in the central part of Western Carpathians, in the Fatra - Tatra region, in the Vel'ká Fatra mountain range. The forest owner is the Banská Bystrica town, managed by the Municipal Forests Ltd. Banská Bystrica.

The permanent sample plots (PSP) were established in the locality Cigarovo, subcompartment $1160 \mathrm{~d}$, which is located on the forest management unit Banská Bystrica in the altitude 390-635 m above sea level. Average annual temperature is $7.1^{\circ} \mathrm{C}$, the mean annual precipitation amounts to $820 \mathrm{~mm}$. Geological constitution of the area is based on carbonate rocks. The predominant soil type is rendzina. The stand is in the category of protection forests, functional type soil-conservation erosion control forests. During the vegetation period 2013, the deluometry quantified the under-canopy erosive-flow of $243 \mathrm{~kg} \cdot \mathrm{ha}^{-1}$. The area of the subcompartment is $8.41 \mathrm{ha}$, average slope is $65 \%$. Typologically $50 \%$ of stand belongs to the group of forest types Tilieto-Aceretum (forest type 4501) and 50\% in Fagetum tiliosum (forest type 4404). The stand is twostoried, the land area of the $1^{\text {st }}$ storey is $2.53 \mathrm{ha}$, age 120 years, the land area of the $2^{\text {nd }}$ storey is 5.88 ha, the age 80 years. From the Forest Management Plan for the years 2009-2018 for this subcompartment were obtained the following data:

$1^{\text {st }}$ storey: stocking 0.10, tree species composition: European beech (Fagus sylvatica L.) $90 \%$ (mean height $26 \mathrm{~m}$, mean diameter $47 \mathrm{~cm}$, mean tree volume $2.15 \mathrm{~m}^{3}$, yield class 24), common yew (Taxus baccata L.) 10\% (mean height $8 \mathrm{~m}$, mean diameter $24 \mathrm{~cm}$, mean tree volume $0.14 \mathrm{~m}^{3}$, yield class 12 ).

$2^{\text {nd }}$ storey: stocking 0.70, tree species composition: European beech (Fagus sylvatica L.) 55\% (mean height $23 \mathrm{~m}$, mean diameter $26 \mathrm{~cm}$, mean tree volume $0.55 \mathrm{~m}^{3}$, yield class 26), European ash (Fraxinus excelsior L.) 30\% (mean height $21 \mathrm{~m}$, mean diameter $24 \mathrm{~cm}$, mean tree volume $0.36 \mathrm{~m}^{3}$, yield class 24), European hornbeam (Carpinus betulus L.) 10\% (mean height $16 \mathrm{~m}$, mean diameter $18 \mathrm{~cm}$, mean tree volume $0.17 \mathrm{~m}^{3}$, yield class 18), sycamore maple (Acer pseudoplatanus L.) 5\% (mean height $22 \mathrm{~m}$, mean diameter $26 \mathrm{~cm}$, mean tree volume $0.53 \mathrm{~m}^{3}$, yield class 26 ).

Total growing stock of the first storey is $420 \mathrm{~m}^{3}$ $\left(50 \mathrm{~m}^{3} \cdot \mathrm{ha}^{-1}\right)$, growing stock of the second storey is $2194 \mathrm{~m}^{3}\left(261 \mathrm{~m}^{3} \cdot \mathrm{ha}^{-1}\right)$. In the plan of felling and tending is specification "without intervention". According to available evidence, there has not been any silvicultural treatment done during last 40 years in the stand. 
On the subcompartment $1160 \mathrm{~d}$ were established 6 permanent sample plots (PSP) with the dimensions $30 \times 30 \mathrm{~m}$. In establishing the PSP was used the Field-Map technology. The network of the PSP is laid out as follows: 2 plots are located in the altitude $600 \mathrm{~m}$ a.s.l., 2 plots in the altitude $500 \mathrm{~m}$ above sea level, and 2 plots in the altitude $400 \mathrm{~m}$ a.s.l. In each altitude is one PSP located in the north-east exposition and one PSP in the south-east exposition. On the individual PSP were recorded the following dendrometric data:

Living individuals with the diameter at $1.3 \mathrm{~m}$ greater than $2 \mathrm{~cm}$ :

- tree species

- tree diameter at $1.3 \mathrm{~m}$ with the precision $1 \mathrm{~mm}$

- tree height with the precision $0.5 \mathrm{~m}$

- crown height with the precision $0.5 \mathrm{~m}$

- position of individual in the coordinate system $x, y$ with the precision $0.1 \mathrm{~m}$

- crown projections 4 dimensions in two perpendicular directions ( $0.1 \mathrm{~m}$ precision)

- functional efficiency of trees by their classifying into three degrees according to Gubka (2011):

1) high efficiency (the tree is stable, well anchored in soil, vital, capable of development, etc.)

2) average efficiency (the tree is stable, with average ability of development, vital, damaged, etc.)

3) low efficiency (the tree is unstable, poorly anchored in soil, leant to slender, with reduced vitality, damaged, drying up, etc.)

- the quality of tree crowns by classification into five degrees according to Gubka (2011):

1) regular crown, fine branches, vital, with the $1 / 2-2 / 3$ size of tree height

2) irregular crown, asymmetrical, vital, with the $1 / 2-2 / 3$ size of tree height

3) regular crown, vital, with the $1 / 3-1 / 2$ size of tree height

4) irregular crown, asymmetrical, vital, with the $1 / 3-1 / 2$ size of tree height or larger but with reduced vitality

5) short crown, up to $1 / 3$ height of tree, asymmetrical, with large-sized branches, damaged, with reduced vitality

- crown type on the basis of the interception method of catching the vertical precipitation according to Ott (1994):
1) umbrella type

2) transitive

3) funnel-shaped

Standing dead trees:

- tree species

- tree diameter at $1.3 \mathrm{~m}$ height with precision of $1 \mathrm{~mm}$

- tree height with the precision of $0.5 \mathrm{~m}$

- position of individual in the coordinate systems $x, y$ with the precision of $0.1 \mathrm{~m}$

- degree of decay by its classification in four degrees according to Albrecht (1990):

1) freshly dead trees

2) incipient decay: loosen bark, after use of an axe wood is still firm, heart rot up to $1 / 3$ of diameter

3) continuing decay: sapwood soft, heartwood here and there firm for an axe, heart rot is greater than $1 / 3$ of diameter

4) heavy rot: wood is soft along its overall length, its main characteristics are not visible

Lying dead individuals:

- tree species

- diameter in the middle of tree with the precision of $1 \mathrm{~cm}$

- length with the precision of $0.1 \mathrm{~m}$

- position of individual - $x, y$ coordinates and direction in which it lies

- degree of decay by its classification in four degrees according to Albrecht (1990) as with standing dead individuals

We measured the lying dead wood with the length greater than $2.0 \mathrm{~m}$ and with half-height diameter $\mathrm{d}_{1 / 2}$ greater than $20 \mathrm{~cm}$, and standing dead wood with the height greater than $2.0 \mathrm{~m}$ and the diameter $\mathrm{d}_{1.3}$ greater than $7 \mathrm{~cm}$.

The evidence of individuals with diameter $\mathrm{d}_{1.3} \leq 2 \mathrm{~cm}$ was accomplished in the transects with the area $10 \times 30 \mathrm{~m}$, established at right angles to the contour. The transect passes through the middle of each PSP. For each individual we registered tree species and tree height. For keeping records was used classification chart according to Korpel' (1989) and the individuals were included in following categories:

1) individuals up to the height $20 \mathrm{~cm}$ (individually recorded individuals according to age from 1 to 5 years)

2) individuals with the height $21-50 \mathrm{~cm}$

3) individuals with the height $51-80 \mathrm{~cm}$ 
4) individuals with the height $81-100 \mathrm{~cm}$

5) individuals with the height over $131 \mathrm{~cm} \mathrm{up}$ to the diameter $2.0 \mathrm{~cm}$ at the height $1.3 \mathrm{~m}$

From the obtained dendrometric data were calculated the tree volumes with the use of volume tables for individual tree overbark volumes (Petráš, Pajtík 1991) and the basal area according to Šmelko (2007). The volume of dead lying individuals was calculated according to Huber's formula (Šmelko 2007).

Classification of individuals in layers was accomplished on the basis of calculated top height of the stand $h_{10 \%}$, which concerned the relatively number $10 \%$ of the thickest trees (Šmelko et al. 2003).

The horizontal canopy of individual PSP was calculated on the basis of crown projections according to Šmelko (2007) methods.

The slenderness coefficient was calculated as a quotient of the height in meters and diameter in centimetres according to Šmelko (2007).

For the analysis of functional dependences among species representation, elevation, and Aspect were used the methods of correlation and regression analysis.

The data were processed by means of Microsoft Excel spreadsheet; statistical characteristics were calculated by the programme STATISTICA 7.0.

\section{Results}

On all permanent sample plots (PSP) is the main tree species European beech (Fagus sylvatica L.) with the average representation $58.9 \pm 7.1 \%$, the stand is further composed of tree species European ash (Fraxinus excelsior L.) $18.6 \pm 3.5 \%$, sycamore maple (Acer pseudoplatanus L.) $10.0 \pm 4.8 \%$, European hornbeam (Carpinus betulus L.) $7.8 \pm 4.8 \%$, common yew (Taxus baccata L.) $3.3 \pm 3.4 \%$, European birch (Betula pendula Roth) $1.1 \pm 1.7 \%$, and silver fir (Abies alba Mill.) $0.4 \pm 0.8 \%$ (Tab. 1 ).

From the analysis of species composition in dependence on altitude follows, that representation of European beech decreases with decreasing altitude from 68.1 on the altitude $600 \mathrm{~m}$ above sea level to $53.3 \%$ on the altitude $400 \mathrm{~m}$ above sea level. With decreasing altitude is increasing the representation of valuable broadleaved species and European hornbeam. The intensity of linear statistical dependence between the altitude and the species representation was expressed by Pearson's correlation coefficient, which reaches the value $r=0.85$ and by the coefficient determination $R^{2}=0.73$, which is according to CoHEN (1988) very strong correlation. The highest occurrence of common yew was recorded at the altitude of $500 \mathrm{~m}$ above sea level. Common yew does not occur on the established plots at the altitude of $400 \mathrm{~m}$ above sea level, what is probably not caused by the altitude itself, but by the better access and by location in the vicinity of human dwellings. In the past, it came to extraction of this tree species, which is witnessed by older yew stumps (Tab. 1).

Intensity of relation between the exposition and the species representation is expressed by Eta coefficient, with the value $\eta=0.28$. Quadrate of Eta coefficient, interpreted as a quotient of variability of numerical variable, which can be explained by the categorical variable $\eta^{2}=0.08$; between the exposition and species representation, according to CoHEN (1988), is only weak correlation.

The average values of the basic characteristics of the forest structure are given in Table 2. The number of individuals with the diameter greater than $2 \mathrm{~cm}$ reached $569 \pm 90 \mathrm{ha}^{-1}$, basal area $29.8 \pm 3.3 \mathrm{~m}^{2} \cdot \mathrm{ha}^{-1}$ and standing volume $316 \pm 34 \mathrm{~m}^{3} \cdot \mathrm{ha}^{-1}$. The presence of dead individuals was found on four PSP with the total value $15.20 \pm 16.91 \mathrm{~m}^{3} \cdot \mathrm{ha}^{-1}$. The main cause of the occurrence of necromass is the spread windthrow disaster (Tab. 2).

The slenderness ratio, calculated as quotient of height in metres and diameter in centimetres fluctuated on the PSP on the level $0.81 \pm 0.04$. The horizontal canopy in the stand fluctuated on the level $79 \pm 10 \%$. From classification of trees into layers follows that the stand is poorly vertically differentiated, and its basis is formed by individuals of upper and partly middle layer. The upper layer is formed by the tree species European beech, European ash, and sycamore maple; the middle layer is formed mainly by European beach, European hornbeam; and the significant constituent of the middle layer is the species common yew. (Tab. 2).

In the stand prevails the funnel-shaped type of crown, typical for the tree species European beech (81.6 $\pm 2.3 \%)$. The transitive type of crown was recorded on $15.2 \pm 3.8 \%$ of trees, and the umbrella type on $3.3 \pm 3.7 \%$ of trees (species common yew and silver fir). For interception of vertical precipitation in the stand is the most suitable the umbrella type of crown (typical for the tree species Norway spruce). On the basic of typological classification of the stands in groups of forest types, and for the comparison with the original species representation according to Hančinský $(1972,1977)$ was found that in the stand is minimal representation of silver fir, and other conifers are absent (Tab. 3). 


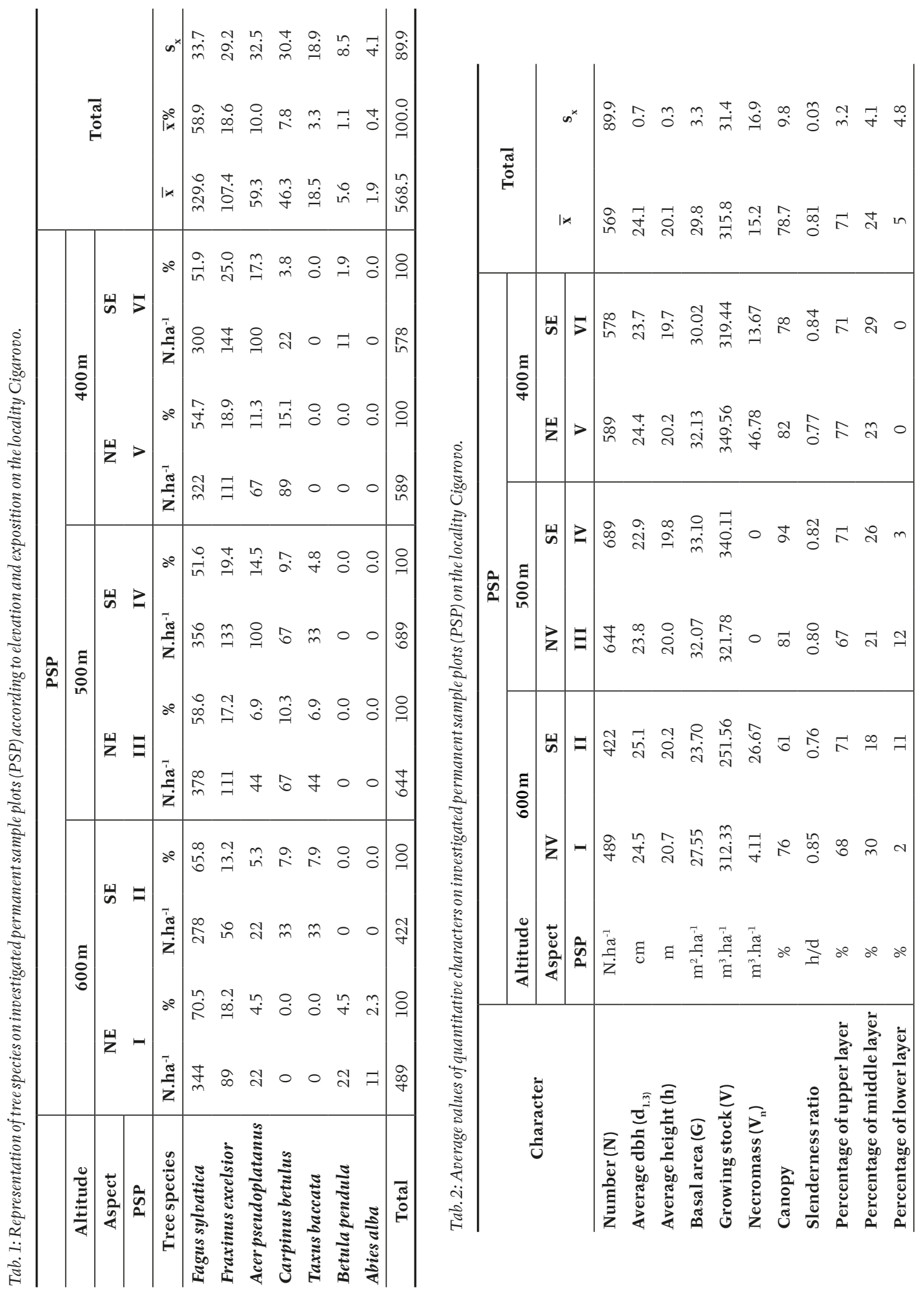




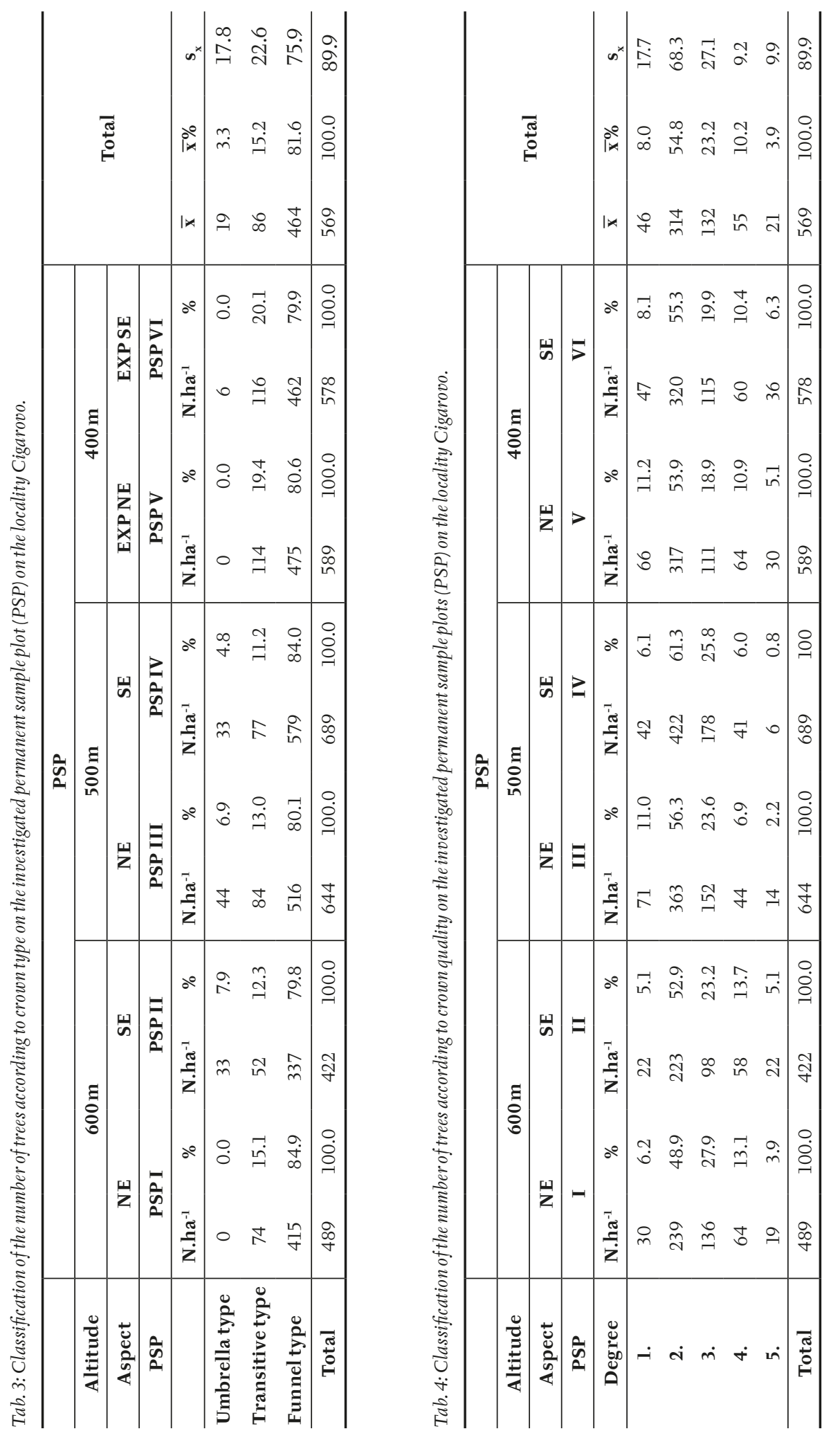




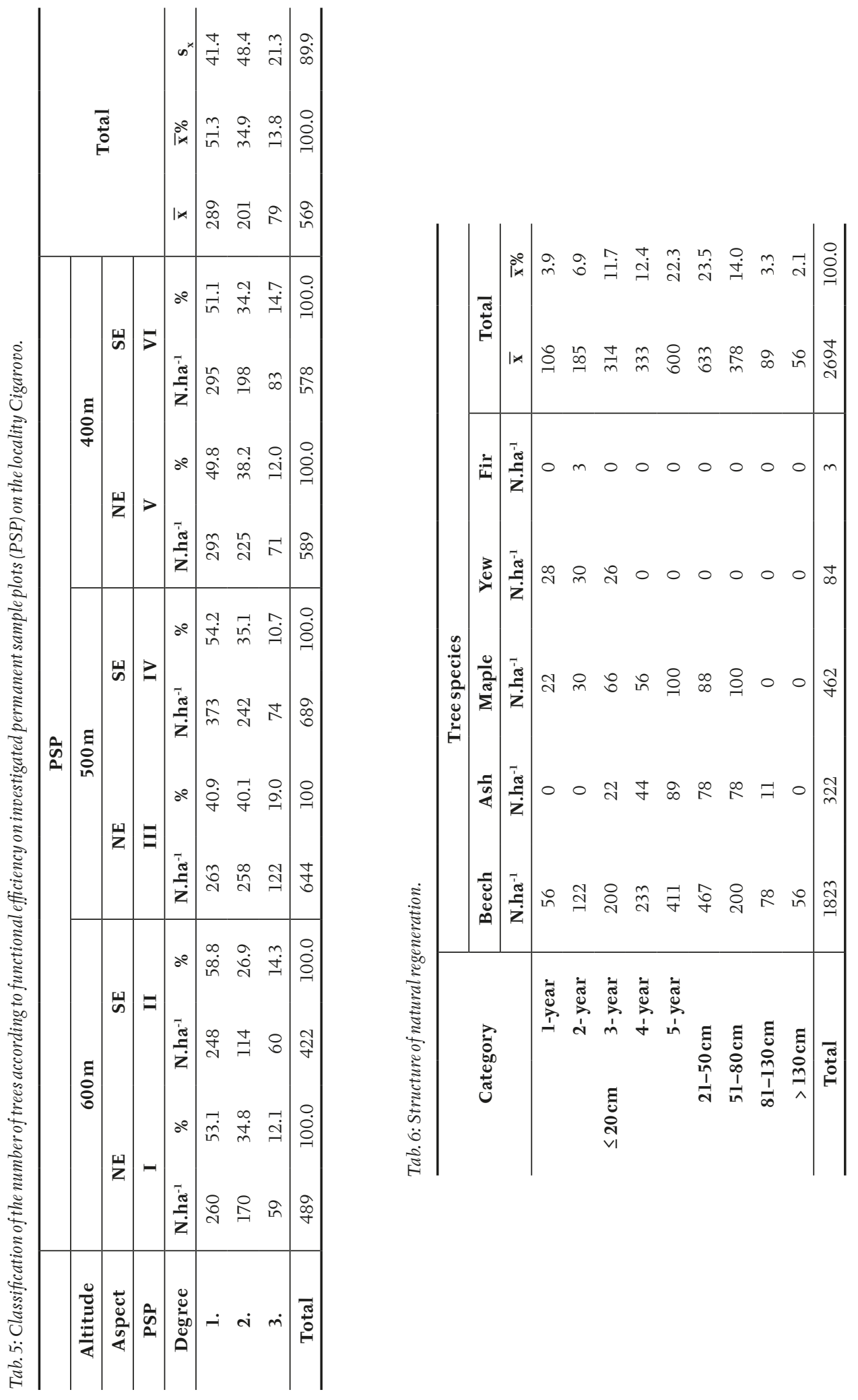


From the evidence of crown quality follows that in the stand prevail trees with irregular, asymmetric, vital crown with the size $1 / 2-2 / 3$ of the tree (degree 2, share $55 \%$ ). The asymmetry of crowns is caused mainly by mutual position of crowns due to the gradient of slope. Into the qualitative degree 1 was classified $8 \%$ of trees, in the degree 3 was placed $23 \%$, into the degree 4 was placed $10 \%$ and $4 \%$ of trees was classified in the degree 5 (Tab. 4).

From classification of trees into three degrees according to functional efficiency follows that $51 \%$ of trees has high functional efficiency (degree 1). An average functional efficiency (degree 2) was recorded with $35 \%$ of individuals. Into degree 3 were included individuals, which from the viewpoint of soil-conservation erosion control objective insufficiently perform their function, that is, the individuals with low efficiency. Their representation corresponds to $14 \%$ of the total numbers of trees (Tab. 5).

From the records of natural regeneration was found, that in the stand is on average 2694 individuals per hectare with the diameter $\mathrm{d}_{13} \leq 2 \mathrm{~cm}$. In species representation of natural regeneration prevails European beech $167.7 \%$, $\left.1823 \mathrm{ha}^{-1}\right)$. From other species occur sycamore maple (17.1\%, $\left.462 \mathrm{ha}^{-1}\right)$ and European ash (12\%, 322 ha $^{-1}$ ) (Tab. 6).

The highest occurrence of natural regeneration was recorded on the PSP II and the PSP V, which is also connected with greater occurrence of necromass. After the dieback of some individuals from the upper layer, the canopy closure was loosen on some parts of the PSP, and therefore improved the condition for natural regeneration. The lowest portion of natural regeneration was recorded on the PSPIV, which is connected with horizontal canopy closure reaching the value up to $94 \%$ here. The intensity of linear statistic relation between canopy closure and abundance of individuals of natural regeneration expressed by means of Pearson's correlation coefficient reached the value $r=-0.99$, and coefficient of determination $R^{2}=0.98$ (almost perfect correlation); abundance of individuals of natural regeneration is decreasing with increasing percentage of canopy closure.

On the stand also comes to natural regeneration of common yew (3.1\%). The individuals of yew are heavy attacked by red deer on the whole object, and before reaching the height $10-15 \mathrm{~cm}$ are almost $100 \%$ browsed. The only exceptions are places inaccessible for red deer (Jankov and Gubka 2012).

\section{Discussion and Conclusion}

The subcompartment $1160 \mathrm{~d}$ is classified in the category of protection forests, the functional type is soil-protection erosion control type. Almost on the whole area of subcompartment were recorded erosion processes in the form of precipitation exomorphic erosion, which are mainly influence by slope, texture and structure of soil. From the viewpoint of observation the erosion processes, the analysed stand and locality are interesting objects from many reasons. The subcompartment with its overall area 8.41 ha is situated on the elevation from 390-635 $\mathrm{m}$ above sea level, which represents as much as 245 meters of altitudinal difference on relatively small area. Extreme slope of terrain (on average $65 \%$, in some parts even more) and terrain conditions significantly increase endangerment of soil by erosion. The subcompartment in it lower part is situated in the vicinity of family dwelling. In the past it came to an undesirable intervention into the stand. Extreme slope and terrain conditions in the middle and in the upper parts of the stand made harvesting operations impossible. It enables to study and compare the positive or negative influence of man. The whole locality is significant also from the reason of increased occurrence of common yew (Taxus baccata L.).

The principal tree species on the stand is European beech (Fagus sylvatica L.), which corresponds with the original tree composition according to Hančinský (1972, 1977). The significant role in connection with the fulfilment of soil-conservation erosion control, in the stand is performed by European ash (Fraxinus excelsior L.) sycamore maple (Acer pseudoplatanus L.), and European hornbeam (Carpinus betulus L.), whose representation decreases with decreasing altitude. Not negligible is the presence of common yew (Taxus baccata L.), which as a part of the middle layer plays significant role in soil stabilisation mainly on extreme sites. From the originally tree species is absent mainly silver fir, whose umbrella crown type according to Ott (1994) would play significant role in interception and attenuation of rainfall.

From the analysis of stand structure follows that the stand is poorly vertically differentiated and its base is formed by upper and partly by middle layers. This decreases its erosion control efficiency. The horizontal canopy is on average level $79 \%$. Necromass creates only $4.5 \%$ from the total growing stock, and the sporadic windthrows are the main reason of occurrence of dead wood. 
The positive phenomenon is the existence of natural reproduction on all PSP which is able sufficiently make up for possible losses of trees from upper and middle layer. An absence of silver fir in natural reproduction is the shortcoming due to minimal representation of this species on the observed PSP.

On the basis of functional efficiency it is possible to state that the observed stand fulfils the requirements lay on the ecosystems with the priority of soil-conservation erosion control, as $51 \%$ of trees were estimated as functionally highly efficient (degree 1), and 35\% of trees as ones with an average functional efficiency. Assessment of protective effect of vegetative cover by use of the universal equation of soil loss (USLE) according to Wischmeier and Smith (1978) is an object of the present research. But an occurrence of erosion phenomena refers to the need of taking measures for their elimination.

It is not advisable to leave the development of communities in protection forest only to natural processes from the reason of probable lost of their functional purpose (Réh 1993, 1999). The most effective and most economic erosion control measure is to manage the structure of stand in order to ensure the permanent and continuous fulfilment of soil-protection erosion control function on each unit of an area (Mayer and Ott 1991; Korpel' and Saniga 1995; Gubka 1997, Saniga 2009; Saniga and Bruchánik 2009). The proposal of measures for improvement of the present state and assurance of sustainable erosion control efficiency follows from the acquired knowledge.

Separate dieback of individuals due to physiological processes, or disturbances, referred to the need of differentiated intervention into individual layers of the stands - purposeful selection. First of all, it is necessary to remove individuals with low functional efficiency ( $3^{\text {rd }}$ degree of efficiency was found with $14 \%$ individuals). Static stability is a very important consideration. Intervention into upper layer ( $1^{\text {st }}$ and $2^{\text {nd }}$ tree class) will modify light conditions and create preconditions for natural regeneration. Consequently, we expect the development of stand with better vertical and species diversity. This should prospectively reflect in the development of quantitative and qualitative indicators.

Organic remains are not of negligible significance in fulfilling erosion function in the forest, because mainly in steep slopes they provide important elements form sediment deposits (Wilford 1984). In accordance with this knowledge it is appropriate to accomplish felling along the contours and leave the wood mass at the stump.
These measures also eliminate contingent damage to the ground cover and remaining trees, when skidding the wood mass.

Soil-conservation erosion control function of forest in the area of interest is closely connected with water management role of forest, since the whole area is a significant source of drinking water for wide surroundings. For that reason, the proper management of forest stands can have the direct positive influence on the quality of life and health for the inhabitants of the whole tributary area.

\section{Literature}

Albrecht, L. 1990: Grundlagen, Ziele und Metodik der Waldökologischen Forschung in Naturwalden: Naturreservate in Bayern. München, Schriftenreihe des Bayerischen Staatsministeriums für Ernärhrung. Landwirtschaft und Forsten gemeinsam mit den Lehrstuhl für Landschaftstechnik, Band 1, 221 pp.

Cohen, J. 1988: Statistical Power Analysis for the Behavioral Sciences. Hillsdale, Lawrence Erlbaum Associates, 567 pp.

DvoŘÁK, J., NovĀK, L. 1994: Soil conservation and silviculture. Amsterdam, Elsevier Science, 399 pp.

GUBKA, K. 1997: Vplyv expozície na štruktúru ochranných lesov na lokalite Podurch [Effect of slope aspect on the structure of protection forests at the locality Podurch (forest district Smolenice)]. Acta facultatis forestalis Zvolen, 39: 107-117.

GuBKA, K. 2006: Pestovné opatrenia v porastoch s protieróznou funkciou [Silvicultural measures in stands with soil protection function]. In: Vplyv štruktúry porastov a pestovných opatrení na zníženie rizika pôdnej erózie (pracovný zošit zeurokurzu). Zvolen, Technická univerzita, 22-24.

GuBKA, K. 2011: Diferencovaná štruktúra brehového porastu vodárenskej nádrže Hriňová [Diferentiated structure of riparianstand of the water-supply storage Hriňová]. In: Ekosystémy v povodiach vodárenských nádrží: zborník vedeckých prác. Zvolen, Technická univerzita, 23-33.

HANČINSKÝ, L. 1972: Lesnétypy Slovenska [Forest types in Slovakia]. Príroda, Bratislava, 307 pp.

HANČINSKÝ, L. 1977: Lesnícka typológia v prevádzkovej praxi [Forest typology in practice]. Príroda, Bratislava, $223 \mathrm{pp}$.

INTRIBUS, R. et al. 1979: Výskum funkcí lesa a zásad obhospodarovania lesov s integrovanými funkciami [Research functions of forests and 
forest management principles with integrated functions]. Súhrnná záverečná správa. Zvolen,VULH, $347 \mathrm{pp}$.

JAKUBis, M. 2006: Protierózna ochrana lesného pôdneho fondu [Anti-erosion protection of forest soils]. In: Vplyv štruktúry porastov a pestovných opatrení na znízenie rizika pôdnej erózie (pracovnýzošitzeurokurzu).Zvolen, Technická univerzita, 3-5.

Jankov, J., GubKa, K. 2012: Prirodzená obnova tisa obyčajného (Taxus baccata L.) v lesoch s protierózno-produkčným zameraním [Regeneration of yew (Taxus baccata L.) in the forests with antierosive-production function]. In: Pestovanie lesa v strednej Európe: zborník vedeckých prác. Zvolen, Technická univerzita, 246-254.

JuRČA, J., BAgAR, R., RÉH, J. 1986: Biotechnika účelových lesủ [Biotechnics of purpose forests]. Praha, SZN, 1986.368 s.

KANTOR, P., ŠACH, F. 2002: Možnosti lesů při tlumení povodní [Possibilities of forest ecosystems to reduce floods]. Lesnická práce, 81(11): 493-495.

Korpel, Š., SAniga, M. 1995: Prírode blízke pestovanie lesa [Close-nature silviculture]. Zvolen, ÚVVP LVH SR, 158 pp.

KoRPEL, Š. 1989: Pralesy Slovenska [Virgin forests of Slovakia]. Bratislava, Veda, Vydavatel'stvo SAV, $332 \mathrm{p}$.

KucbeL, S. 2005: Štruktúra a regeneračné procesy porastu s dominantnou pôdoochrannou funkciou [Structure and regeneration processes of stand with dominant soil-conservation function]. Acta facultatis forestalis Zvolen, 47:195-206.

MAYeR, H., Отт, E. 1991: Gebirgswaldbau - Schutzwaldpflege. Stuttgart, Gustav Fischer Verlag, 587 pp.

MidRIAK, R. 1979: Pôdoochranná funkcia lesov a odôvodnenie zásad hospodárenia za účelom uplatnenia tejto funkcie [Soil protection function of the forest and substantiation of management principles in order to perform this function]. Súhrnná záverečná správa. Zvolen,VÚLH, 224 pp.

MidRIaK, R. et al. 1981: Diferencované obhospodarovanie lesa podl'a integrovaných funkcií [Diferential forest management according to integrated functions]. Lesnícke štúdie 31. Bratislava, Príroda, 222 pp.

Отто, H. J. 1994: Waldökologie. Stuttgart, Ulmer, 391 pp.

Petráš, R., Pajtík, J. 1991: Sústava československých objemových tabuliek drevín [Czechoslovak system volume tables wood]. Lesnícky časopis, 37(1): 49-56.
PodrÁzský, V., KupKa, I. 2011: Vliv lesních dřevin a lesnických zásahů na hydrofyzikální charakteristiky půd - krátke sdělení [Effects of forest tree species and forestry treatments on hydrophysical soil characteristics - short communication]. In: Ekosystémy v povodiach vodárenských nádrží: zborník vedeckých prác. Zvolen, Technická univerzita, 99-103.

RÉH, J. 1993: Hospodárenie v účelových lesoch [Management of purpose forests]. Zvolen, ES TU vo Zvolene, $213 \mathrm{pp}$.

RéH, J. 1999: Pestovanie účelových lesov [Silviculture of purpose forests]. Zvolen, Technická univerzita, $218 \mathrm{pp}$.

Röhrig, E., Bartsch, N., Dengler A. 1992: Waldbau auf ökologischer Grundlage - Der Wald als Vegetationsform und seine Bedeutung für den Menschen. Band 1. Hamburg - Berlin, Parey Verlag, 350 pp.

SANIGA, M., BRUCHÁNIK, R. 2009: Prírode blízke obhospodarovanie lesa [Close nature forest stand management]. Zvolen, Národné lesnícke centrum, $104 \mathrm{pp}$.

SAniga, M., Zrak, J., DankovÁ, L., JAD̆UD̆, J. 2011: Štruktúra lesa a jeho zrážkový režim [Forest structure and its rainfall regime]. In: Ekosystémy $\mathrm{v}$ povodiach vodárenských nádrǒi : zborník vedeckých prác. Zvolen, Technická univerzita, 105-111.

SAniga, M. 2009: Pestovanie lesa [Silviculture]. Zvolen, Technická univerzita, 310 pp.

ŠmeLKo et al. 2003: Meranie lesa a dreva [Forest and wood measurement]. Zvolen, ÚVVP LVH SR, 239 pp.

ŠMELKo, Š. 2007: Dendrometria [Forest mensuration]. Zvolen, Technická univerzita 401 pp.

VALTÝNI, J. 2001: Lesy a povodne [Forests and floods]. Vedecké štúdie 5/2001/A. Zvolen, Technická univerzita, $46 \mathrm{pp}$.

Wilford, D. J. 1984: The sediment-storage function of large organic debris at the base of unstable slopes. In: Fish and Wildlife Relationships in Old-Growth Forests : proceedings of a symposium. Juneau, Alaska, American Institute of Fishery Research Biologists, 115-119.

Wischmeier, W. H., Smith, D. D. 1978: Predicting Rainfall Erosion Losses - A Guide to Conservation Planning. Washington D.C., USDA, Agricultural Handbook No. 537, 58 pp.

LESNÝ HOSPODÁRSKY PLÁN pre LC Mestské lesy s. r. o. Banská Bystrica - Ul'anka na roky 20092018 [Forest management plan for management unit Banská Bystrica - Ul'anka, years 2009 - 2018]. Zvolen, Euroforest s.r.o.

ZeLENÁ SPRÁVA 2013 [Green report 2013]. Správa o lesnom hospodárstve Slovenskej republiky za rok 2012 [online]. Bratislava : Minis- 
terstvo pôdohospodárstva SR, [cit. 2014-1802]. Available on the Internet: http://www. mpsr.sk/sk/index.php?start\&language $=$ sk \&navID $=1 \& i d=8150$

Vyhláška MP SR č. 453/2006 o hospodárskej úprave lesov a ochrane lesa [Edict MP SR no. 453/2006 about forest regulation and protection].

Zákon č. 326/2005 Z. z. o lesoch [Law no. $326 / 2005$ about forests]. 
